Pobrane z czasopisma Annales I - Philosophy and Sociology http://philosophia.annales.umcs.pl Data: 26/04/2023 11:31:22

DOI: $10.17951 / \mathrm{i} .2018 .43 .2 .107-121$

A N N A L E S

UNIVERSITATIS MARIAE CURIE-SKŁODOWSKA

LUBLIN - POLONIA

VOL. XLIII, 2

SECTIO I

2018

\title{
JACEK GURCZYŃSKI
}

ORCID: 0000-0001-8679-1357

Uniwersytet Marii Curie-Skłodowskiej w Lublinie

Pojęcie matryc M. Ostrowickiego - analiza i krytyka ${ }^{1}$

The Notion of Matrix by M. Ostrowicki. Critical and Analytical Frame

Przeprowadzone przez M. Ostrowickiego analizy są w zasadzie jedyną obecną w literaturze przedmiotu próbą systemowego opisu ontologii sfery wirtualnej ${ }^{2}$. Już chociażby ze względu na swoją pionierskość teoria matryc Ostrowickiego zasługuje na szersze omówienie. Najważniejszym pojęciem wprowadzonym przez Ostrowickiego, służącym do opisu wirtualności, jest pojęcie matrycy (matrix), rozumianej jako pewna struktura cybernetyczna przetwarzająca informacje. Podstawową cechą matryc jako bytu cybernetycznego są związki sterowania ${ }^{3}$. Sterowanie jest cechą charakteryzującą wszelkie byty: jest powszechne, tworzy istotę wszelkich bytów. „Innego typu sterowanie tkwi w człowieku, inne w zwierzętach, roślinach, przedmiotach realnych, dziełach sztuki czy ideach - pozostając sterowaniem"4. Sterowanie może być binarne (automaty) lub probabilistyczne (np. sterowanie systemów biologicznych nie może być dokładnie opisane w modelu, gdyż odbywa się na zasadzie czarnej skrzynki) $)^{5}$. Świat jest zatem zespołem dynamicznych układów wzajemnie na siebie oddziałujących i połączonych procesami sterowania - sterowanie jest powszechne, dotyczy tego, co ożywione i nieożywione. Ostrowicki proponuje więc bardziej funkcjonalistyczny niż esencjalny opis rzeczywistości. Prawdopodobnie jest to jedyna możliwość w przypadku, gdy nie dysponujemy metafizyką świata realnego. Trzeba zaznaczyć, że Ostrowicki odróżnia od siebie pojęcia „realności” oraz „rzeczywistości”. Pojęcie „realności”

\footnotetext{
1 Niniejszy artykuł, w nieco zmienionej, krótszej wersji, ukazał się wcześniej w: J. Gurczyński, Czym jest wirtualność. Matrix jako model rzeczywistości wirtualnej, Lublin 2013.

2 M. Ostrowicki, Wirtualne realis. Estetyka w epoce elektroniki, Kraków 2006, s. 61-135.

3 Ibidem, s. 61, 80, 84.

4 Ibidem, s. 76. Na temat powszechności sterowania zob. ibidem, s. 77, 80.

5 Ibidem, s. 77.
} 
jest związane z (domniemanym, bo przecież co do jego istnienia nigdy nie uzyskaliśmy pewności) istnieniem zastanego świata zewnętrznego, natomiast pojęcie „rzeczywistości” ma szerszy zakres - obejmuje m.in. wartości, idee, byty intencjonalne, możliwe, realne, ,czyli to wszystko, co tworzy świat człowieka w najszerszym kontekście"6.

Pojęcie sterowania jest jednym z kluczowych pojęć w systemie Ostrowickiego. Czym zatem jest, na czym polega i jak należy je rozumieć? Odwoływanie się do cybernetyki - twierdzenie, iż rzeczywistość ma naturę cybernetyczną wskazywałoby na to, że sterowanie, podobnie jak w cybernetyce, opiera się na układach sprzężeń zwrotnych. Ostrowicki stwierdza jednak, że „teoria wynika z założeń cybernetyki o powszechności sterowania, praktyka nie ujawnia do końca, czym sterowanie jest, pokazuje raczej na zasadzie czarnej skrzynki, jak system działa" . Kluczowe dla teorii pojęcie sterowania pozostaje więc w zasadzie niewyjaśnione, co należy uznać za istotny brak proponowanego rozwiązania. Można domniemywać, że chodzi tu o jakiś rodzaj relacji determinowania, lecz autor nie dookreśla charakteru tej relacji.

Ostrowicki proponuje następujący podział matryc cybernetycznych:

1. Matryca filozoficzna - opisuje rzeczywistość; składają się na nią poszczególne, jednostkowe systemy filozoficzne; matryca ta nakierowuje podmiot poznający na sferę intencjonalną, która jest odrębna od niedostępnej w pełni realności ${ }^{8}$.

2. Matryca artystyczna - służy emergencji wartości, wyobrażeń, idei, znaczeń; matryca ta niczego nie symuluje, lecz raczej wyłania, niczego nie bada ani nie zakłada; ,pozostałe matryce, kreując rzeczywistość realis, w efekcie zrywają referencyjność w stosunku do zakładanej realności, wydaje się, że w przeciwieństwie do pozostałych, matryca artystyczna mogłaby posłużyć wyłonieniu istnienia realności - świata realnego lub matrycy realności - co łączyłoby się z koniecznością intersubiektywizacji sztuki"9.

3. Matryca medialna - służy symulowaniu rzeczywistości; niczego nie poszukuje ani nie wyjaśnia; „kreuje symulowany pod kątem socjotechnicznym obraz rzeczywistości”"10.

4. Matryca technologiczna - służy tworzeniu rzeczywistości człowieka: realis matrycy; tworzy alternatywną dla realności sferę; jest możliwa dzięki technologiom cyfrowym; „tworzy obiektywną przestrzeń elektronicznego realis”"11.

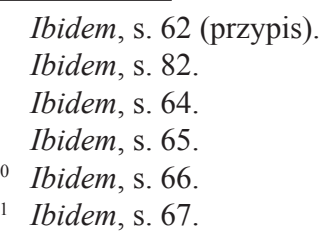


Pobrane z czasopisma Annales I - Philosophy and Sociology http://philosophia.annales.umcs.pl Data: 26/04/2023 11:31:22

Pojęcie matryc M. Ostrowickiego - analiza i krytyka

W swoich rozważaniach skupię się na matrycy technologicznej jako tej, która tworzy pewną obiektywną, a jednocześnie taką, której istnienia jesteśmy pewni, rzeczywistość - rzeczywistość istot świadomych, stworzoną przez nie same, dlatego mających do niej nieograniczony dostęp, mogących ją dowolnie zmieniać, przetwarzać, dostosowywać do swoich potrzeb, a może nawet i unicestwić.

Ze względu na to, że matryce są tworami cybernetycznymi podlegającymi sterowaniu, również wszelkie matryce są w jakimś stopniu interaktywne, ale „tylko matryca technologiczna wydaje się w takim stopniu interaktywna, że pod tym względem przerasta inne matryce lub rzeczywistość zakładanego świata realnego. [...] Rzeczywiste »wejście« i działanie podmiotu jest możliwe tylko w matrycy technologicznej"12. Jedynie matryca technologiczna może służyć wytworzeniu elektronicznego realis, które będzie równoważne lub nawet przewyższające zakładaną realność. To właśnie nowe technologie cyfrowe zapewniają szybki rozwój, ewolucję i powiększanie się sfery wirtualnej.

Matryce są tworem człowieka, mają swoje źródło w podmiocie, są antropiczne. Ponadto są tworami złożonymi ze struktur konstytutywnych i funkcjonalnych ${ }^{13}$. Treść matrycy (realis matrycy) ma genezę w świadomości podmiotu - owa treść jest czysto świadomościowa albo zawiera elementy domniemanego świata zewnętrznego ${ }^{14}$. Matryce są transcendentne w stosunku do stanów świadomości podmiotu, tworzą osobną obiektywną sferę rzeczywistości świata podmiotu - sferę wirtualną, która jest złożona z połączonych ze sobą matryc. Ostrowicki podkreśla autonomiczność i obiektywność sfery wirtualnej - istnienie wirtualności nie wymaga podtrzymywania aktami świadomości ${ }^{15}$. Informacje zewnętrzne (dane wejściowe) są przetwarzane przez mózg - owo przetwarzanie danych może występować na poziomie świadomym lub podświadomym, w wyniku czego powstaje świadomościowy/podmiotowy obraz świata ${ }^{16}$. „[Ś]wiat człowieka jest zbiorem matryc, których metafizycznej genezy nie jesteśmy w stanie wskazać. Matryce, jako rzeczywistość człowieka, jego wytwór, istnieją w sensie ontologicznym niezależnie od podmiotu i zakładanej rzeczywistości, np. świata realnego" ${ }^{17}$. Zatem

12 Ibidem, s. 115-116.

13 Ibidem, s. 69-75. Struktury konstytutywne odpowiadają za autonomiczność, generatywność, formalność, genetykę i genealogię. Struktury funkcjonalne odpowiadają za dynamikę, interaktywność, akomodację, asymilację i inwazyjność. Szczegółowe omówienie wszystkich tych struktur w przypadku prowadzonych tu rozważań nie jest konieczne.

14 Zob. ibidem, s. 63-64, 68, 84, 87.

15 Zob. ibidem, s. 63, 74, 88, 94, 95.

16 Ibidem, s. 104. Zauważmy, że każdy obraz świata, czy to realnego, czy wirtualnego, czy fikcyjnego, czy jakiegokolwiek innego, zawsze ma charakter podmiotowy - odciśnięte swoiste piętno podmiotu tworzącego dany obraz.

17 Ibidem, s. 84. 
sfera wirtualna jest tworem świadomości podmiotu, wynikiem intencjonalnych działań podmiotu, rodzajem bytu intencjonalnego. Przy takim rozumieniu terminu wirtualność obejmuje wszystko to, co zostało wytworzone świadomościowo - wirtualność określa genezę dla wszelkich wytworów ludzkiej świadomości ${ }^{18}$.

Konsekwencją tak szerokiego pojmowania wirtualności jest ontologiczna homogenizacja sfery wirtualnej - wszelkie byty uzyskują ten sam sposób istnienia i mogą być rozpatrywane na wspólnej płaszczyźnie wirtualnego realis, co gwarantowane jest przez obiektywny status wirtualności. Według Ostrowickiego wirtualność ułatwia podmiotowi dostęp np. do wartości czy jakości, które w sferze realności są trudniej dostępne ze względu na wielość płaszczyzn ontologicznych ${ }^{19}$. Ma to świadczyć o przewadze sfery wirtualnej nad realną. Zauważmy, że taka ontologiczna homogenizacja jest możliwa tylko wówczas, gdy sam podmiot nie jest elementem sfery wirtualnej - wtedy faktycznie wszelkim wirtualnym bytom przysługuje ten sam sposób istnienia. Jest to sytuacja podobna do tej z Matrixa dla członków załogi Nabuchodonozora świat Matrixa oglądany z zewnątrz jest jednolity ontologicznie: wszelkie byty istnieją w taki sam sposób, są generowane komputerowo, mają charakter cyfrowy. Jednak dla mieszkańców Matrixa generowany komputerowo świat, w którym przebywają, nie jest już oczywiście ontologicznie jednolity, lecz - podobnie jak świat realny - składa się z wielu różnych płaszczyzn ontologicznych. Mamy więc dwie możliwości: 1) jednolity ontologicznie świat postrzegany przez podmiot z zewnątrz, z poziomu innego świata, w którym występuje wiele płaszczyzn ontologicznych; 2) zróżnicowany ontologicznie świat, w którym egzystuje podmiot mogący podejmować różnego rodzaju działania. Jeśli Ostrowicki twierdzi, że sfera wirtualna jest ontologicznie jednolita, to jednocześnie musi przyjąć, że istnieje jakaś inna sfera ontyczna, której elementem jest dany podmiot i z poziomu której postrzega on sferę wirtualną. Podmiot kreuje sferę wirtualną, lecz sam jest bytem zamieszkującym jakiś inny nadrzędny, bardziej pierwotny ontycznie świat - może być twórcą i widzem, ale nie uczestnikiem wirtualności. Taka konsekwencja pozostaje w niezgodzie $\mathrm{z}$ twierdzeniem Ostrowickiego, iż sfera wirtualna „to jedyna w pełni dostępna sfera człowieka” oraz że „wirtualne realis może stać się bliższe człowiekowi, ważniejsze niż realność - podmiot odnajduje w niej swój swoisty świat, który jest w mniejszym stopniu obcy niż świat realny" ${ }^{\prime 20}$. Postulaty te mogą być spełnione tylko wówczas, gdy uznamy, że pełne uczestnictwo w wirtualności wiąże się z wielopłaszczy-

18 Należałoby zatem uznać, że przy takim ujęciu pojęcia wirtualności i sfery przedmiotów czysto intencjonalnych (rozumianych po ingardenowsku) są pojęciami równozakresowymi.

19 M. Ostrowicki, Wirtualne realis..., s. 90.

20 Zob. ibidem, s. 92, 109-110, 114. Podobne twierdzenie, że sfera wirtualna jest dla człowieka bardziej pociągająca niż świat realny, można znaleźć w: D. Weberman, The Matrix Simulation 
Pobrane z czasopisma Annales I - Philosophy and Sociology http://philosophia.annales.umcs.pl Data: 26/04/2023 11:31:22

znową ontologią wirtualności. Ale w takim przypadku musimy także przyjąć, że budowanie relacji człowieka ze sferą wirtualną - ze względu na jej heteronomiczność ontologiczną - jest równie skomplikowane, jak w przypadku domniemanego świata realnego. W efekcie nie można byłoby tu wskazywać na przewagę sfery wirtualnej nad realną.

Mówiąc o intencjonalności, Ostrowicki odwołuje się zarówno do R. Ingardena, jak i D. Dennetta. Na płaszczyźnie ontologicznej sfery podmiotu i przedmiotów intencjonalnych są wzajemnie transcendentne - tu autor wskazuje na podobieństwo do Ingardenowskiej sfery czysto intencjonalnej. Przypomnijmy, że według Ingardena intencjonalność jest podstawową (istotną i konieczną) cechą świadomości w ogóle, natomiast pozostaje dystynktywną cechą wszelkich form świadomości aktywnej ${ }^{21}$. Inaczej ujmuje to Dennett, ponieważ traktuje intencjonalność instrumentalnie - wynika ona z naszego nastawienia intencjonalnego (intentional stance). Intencjonalność nie jest cechą świata, lecz naszym sposobem ujmowania świata - w oparciu o to możemy wyjaśniać i przewidywać ${ }^{22}$. Tak też należy rozumieć stwierdzenia Ostrowickiego, gdy ten, odwołując się do Dennetta, mówi, że intencjonalność jest cechą wszystkich tych bytów, których działanie ma przyszłość, których zachowanie da się przewidzieć czy wyjaśnić z punktu widzenia nastawienia intencjonalnego. Intencjonalność nie jest już dystynktywną cechą

and the Postmodern Age, [w:] W. Irwin (ed.), The Matrix and Philosophy. Welcome to the Desert of the Real, Chicago 2002, s. 233-235.

21 J. Dębowski zwraca uwagę na to, że „świadomościowość” (Bewusstseinsheit) świadomości, czyli jej cechę dystynktywną (wyróżniającą), stanowi w terminologii Ingardena przeżywaniowość (od niem. Durchleben), cecha zwana też refleksywnością (w odróżnieniu od refleksyjności) - intencjonalność nie jest dystynktywną cechą świadomości, gdyż można mówić np. o intencjonalności zombie czy - jak robił to M. Marleu-Ponty - o intencjonalności żywego ludzkiego ciała. Zob. J. Dębowski, Świadomość, poznanie, naoczność poznania, Lublin 2001, s. 20-22, 56-66. Faktycznie, gdy rozpatrujemy świadomość w ogóle, to według Ingardena, który mówi o różnych stopniach świadomości, w najbardziej pierwotnym, całkowicie biernym stadium wyróżnikiem świadomości pozostaje przeżywaniowość. „Bezwzględnie bierna świadomość to czyste doznawanie jakichkolwiek dat w prostym współpłynięciu z nimi w coraz to nowych chwilach, bez specjalnego »uświadamiania sobie«, co to jest właściwie, co się odczuwa lub czego się doznaje, ani też nawet bez »uświadamiania sobie«, że nadchodzą wciąż nowe chwile lub że minione właśnie minęły. W tym sposobie doznawania nie uświadamiamy sobie także, że to, co odczuwamy, jest jakoś od nas samych różne" - R. Ingarden, Spór o istnienie świata, t. 2, Warszawa 1961, s. 6-7. Na tym poziomie jeszcze nie dochodzi do konstytuowania się podmiotu (Ja) ani też nie ma tu jeszcze mowy o żadnym przedmiocie intencjonalnym. Jednak już najbardziej pierwotne formy świadomości aktywnej według Ingardena cechują się intencjonalnością, „wzrastające z nagle obudzonej ciekawości zwrócenie się ku temu, czego właśnie doznajemy" (ibidem, s. 8). Ze względu na to, że w prowadzonych tu rozważaniach interesuje nas jedynie świadomość aktywna - gdy występuje już rozróżnienie pomiędzy podmiotem a przedmiotem intencjonalnym - można byłoby utrzymywać, że intencjonalność jest dystynktywną cechą świadomości (aktywnej).

22 Zob. D. Dennett, Intentional Stance, Cambridge-London 1987, zwłaszcza s. 13-34, 69-80. 
świadomości (aktywnej), lecz można ją przypisać też takim bytom, jak np. samopowielające się makrocząsteczki, termostaty, ameby, rośliny, komputery szachowe itd. Ostrowicki podkreśla jednak, że człowiek charakteryzuje się odmiennym od innych, wyróżnionym typem intencjonalności. Czym innym jest zdolność uświadamiania czy przedstawiania przedmiotu myśli, a czym innym teleologia nieświadomego działania. Przyjmując, że cała rzeczywistość ma charakter cybernetyczny (powszechność procesów sterowania), należy przyjąć, że „intencjonalność tkwi w jakiejś formie w całej rzeczywistości i ma podłoże cybernetyczne, jak również że intencjonalność może być właściwością cybernetycznego świata, a nie jedynie własnością człowieka"23. Taki sposób ujęcia intencjonalności budzi jednak wątpliwości. Jeżeli przyjmiemy, że człowieka charakteryzuje wyróżniona forma intencjonalności - odmienna od wszelkich innych typów intencjonalności - to równie dobrze możemy zrezygnować z determinatora „wyróżniony” i powtórzyć za Ingardenem, że intencjonalność jest dystynktywną cechą świadomości (aktywnej), ponieważ żaden inny byt owej cechy nie posiada. Stwierdzenia, że intencjonalność jest cechą dystynktywną świadomości aktywnej oraz że człowiek charakteryzuje się wyróżnionym typem intencjonalności, są w zasadzie sobie równoważne - jedyną występującą tutaj różnicą jest różnica syntaktyczna, polegająca na użyciu wyrażeń o odmiennym kształcie.

Opisując sferę wirtualną, Ostrowicki wskazuje jej cechy charakterystyczne:

- sfera wirtualna pozostaje otwarta na różne interpretacje, co jest cechą właściwą wszelkich tworów świadomości (zauważmy jednak, że podobnie jest też w przypadku domniemanego i istniejącego niezależnie od naszej świadomości świata fizycznego - por. np. wielość różnych, niezgodnych ze sobą interpretacji mechaniki kwantowej, jak: interpretacja kopenhaska, teoria zmiennych ukrytych, hipoteza Wieloświata, dekoherencja kwantowa itd.),

- podmiot może kształtować sferę wirtualną zgodnie z własnymi potrzebami i dążeniami ${ }^{24}$,

${ }^{23}$ M. Ostrowicki, Wirtualne realis..., s. 98-99. Zauważmy, że przy tak dużych różnicach w pojmowaniu intencjonalności problematyczna pozostaje próba pogodzenia teorii intencjonalności Ingardena z teorią Dennetta, a zatem problematyczne jest również jednoczesne odwoływanie się do obydwu teorii.

${ }^{24}$ Jest to możliwe jedynie w przypadku, gdy sfera wirtualna ma charakter czysto i wyłącznie świadomościowy, jest myślą kształtowaną przez myśl. Ale w takim przypadku zupełnie nieistotna staje się matryca technologiczna - cała sfera przedmiotów czysto intencjonalnych kształtowana świadomościowo bez zapośredniczenia przez jakąkolwiek technologię może być kształtowana całkowicie dowolnie, zgodnie z własnymi potrzebami, dążeniami, kaprysami - moglibyśmy powtórzyć za Schopenchauerem, że świat jest naszą wolą i wyobrażeniem; i tak jest w przypadku dowolnej sfery ontycznej mającej swój fundament bytowy w świadomości. 
Pobrane z czasopisma Annales I - Philosophy and Sociology http://philosophia.annales.umcs.pl Data: 26/04/2023 11:31:22

Pojęcie matryc M. Ostrowickiego - analiza i krytyka

- matryce, składające się na sferę wirtualną, wchodzą w interakcje zarówno pomiędzy sobą, jak i podmiotami, a w efekcie ewoluują ${ }^{25}$,

- matryce są treściowo bogatsze od domniemanej realności. To bardzo mocne stwierdzenie (czy może raczej założenie) i bardzo trudne do utrzymania. Według Ingardena przedmioty realne charakteryzują się zupełnością ontologiczną, czego bezpośrednią konsekwencją jest fakt, że posiadają nieskończenie wiele cech (determinacji) przy założeniu, że istnieją nie tylko własności proste, ale i złożone. Natomiast sfera czysto intencjonalna, jako byt wytworzony przez skończoną świadomość w ciągu skończonego czasu, z konieczności jest niezupełna ontologicznie, w poszczególnych przedmiotach czysto intencjonalnych występują miejsca niedookreślenia, czyli wszelkie obiekty czysto intencjonalne (czy, mówiąc ogólniej, wszelkie obiekty wytworzone przez skończoną świadomość) z konieczności mogą posiadać jedynie skończoną liczbę cech/ determinacji. $Z$ tego punktu widzenia twierdzenie Ostrowickiego mówiące, że matryce (będące przecież tworami świadomościowymi) są treściowo bogatsze od świata realnego, wydaje się wątpliwe,

- świadomość i sfera wirtualna są charakteryzowane przez pojęcia immaterii i intencjonalności, a nie przez pojęcia fizyczności czy realności ${ }^{26}$,

- podmiot ma pierwszoosobowy, nieograniczony i bezpośredni dostęp do sfery wirtualnej, gdyż jest ona jego tworem (to kartezjańskie, czy może nawet bardziej buddyjskie, ujęcie rzeczywistości, zgodnie z którym wszystko jest myślą i dlatego to właśnie myśl ma siłę sprawczą),

- sfera wirtualna jest wytworem świadomości, a zatem jest ontologicznie względem świadomości pochodna ${ }^{27}$.

25 Stwierdzenie takie, mimo pozorów oczywistości, wymaga jednak uzasadnienia - możliwa jest przecież sytuacja, w której efektem interakcji jest inwolucja, a nie ewolucja, rozkład, a nie rozwój (np. każdy nasz oddech prowadzi do reakcji spalania, czyli niszczenia czegoś, czy, mówiąc inaczej, każdy nasz oddech, niezbędny dla podtrzymania naszego życia, przybliża nas jednocześnie do nieuchronnego końca).

26 Niestety, Ostrowicki nie dookreśla bliżej tego, czym jest immateria; nie podaje nawet podstawowych różnic pomiędzy sferą czysto intencjonalną a immaterialną.

$27 \mathrm{~W}$ innym miejscu Ostrowicki wskazuje następujące cechy środowisk elektronicznych: „Dziesięć prawd o świecie elektronicznym: 1. Świat elektroniczny jest alternatywną rzeczywistością w stosunku do świata fizycznego. 2. Świat elektroniczny jest światem człowieka, zdolnym przyjąć wnoszone tam człowieczeństwo, zawiera ludzkie emocje i uczucia oraz wartości duchowe. 3. Swiat elektroniczny to rzeczywistość dla przemieszczenia wszelkiej aktywności życiowej człowieka; jest źródłem autokreacji i kreacji, własnych poszukiwań i ekspresji. 4. Świat elektroniczny jest źródłem możliwości odmiennych od znajdowanych w świecie fizycznym. 5. Świat elektroniczny może być przedmiotem wyborów egzystencjalnych, ludzkich decyzji dotyczących rzeczywistości, w której ludzie pragną przeżywać swoje życie. 6. Świat elektroniczny jest immaterialny, ma przestrzeń odmienną niż świat fizyczny. 7. Świat elektroniczny powiększa swoje możliwości wraz 
Rozpatrując sposób istnienia wirtualności, Ostrowicki wskazuje na dwie możliwości opisu tego zagadnienia. Pierwszy jest związany z akceptacją idealizmu metafizycznego - powiemy wówczas, że wirtualność istnieje w sposób immaterialny. „,[M]atryce nie są ani realne, w rozumieniu świata realnego, ani immanentne, w rozumieniu stanów świadomości podmiotu, tworzą sferę wirtualną, cybernetyczną i immaterialną, są realis wirtualnym człowieka, sferą egzystencji - hipotetycznie byłyby jedyną płaszczyzną ontologiczną"28. Drugi sposób polega na odwołaniu się do nauk szczegółowych i przyjęciu np. korpuskularno-falowej teorii budowy materii. „Jeśliby zmierzać do opisania zakładanej rzeczywistości jako kwantowej, to być może problem immaterialności sfery wirtualnej uzyskałby dodatkowe wsparcie z poziomu współczesnej fizyki, co mogłoby prowadzić do np. dookreślenia dodatkowej matrycy świata realnego [... $]^{\prime 29}$.

Podsumowując swoje rozważania, Ostrowicki stwierdza:

Matrycowość rzeczywistości tworzyłaby jednorodną i jedyną perspektywę filozoficzną, sprowadzoną do pojęcia matrycy jako źródła tworzenia wszelkich opisów, w tym systemowego, za którymi już nic nie stoi (albo nie jesteśmy w stanie do tego dotrzeć). [...] Interesuje nas tylko sfera wirtualna, jej struktura i istnienie, a nie analiza zakładanego świata realnego. Stanowisko rodzi się i wynika ze swoistej niemocy stawiania postulatów odnośnie do realności ${ }^{30}$.

Analizując zjawisko wirtualności z wykorzystaniem pojęcia matrycy jako tworu cybernetycznego i intencjonalnego, Ostrowickiemu udaje się zaproponować nie tylko pewną lokalną ontologię wirtualności, lecz także wykorzystać wypracowane pojęcia do opisu o wiele bardziej ogólnego - mianowicie przedstawienia pewnej systemowej propozycji opisu całości rzeczywistości podmiotu.

z rozwojem technologii. 8. Świat elektroniczny ewoluuje szybciej niż świat fizyczny, wpływając na ewolucję człowieka. 9. Świat elektroniczny nie jest symulacją i nie ma w nim miejsca na symulację. 10. Świat elektroniczny to rzeczywistość, gra pozostaje w świecie fizycznym"- M. Ostrowicki, Tożsamość człowieka w środowisku elektronicznym, „Kwartalnik Filmowy” 2008, nr 62-63, s. 151. Tekst ten został opublikowany pod imieniem Sidey Myoo, którego autor używa w środowisku elektronicznym alternatywnie do imienia i nazwiska Michał Ostrowicki, używanego w świecie realnym/fizycznym. Trzeba podkreślić, że autor jest nie tylko teoretykiem środowisk elektronicznych, ale również ich aktywnym i twórczym uczestnikiem. W 2007 r. Ostrowicki założył w środowisku Second Life „Academia Electronica” - niezinstytucjonalizowany ośrodek, w którym podczas roku akademickiego odbywają się wykłady otwarte dla uczestników Second Life. „Możliwość spotkania w elektronicznej sali konferencyjnej uniezależnia od przestrzeni fizycznej, jak również umożliwia jednoczesne prowadzenie wykładów w dwóch rzeczywistościach: elektronicznej i świata fizycznego" (ibidem, s. 113).

\footnotetext{
28 Idem, Wirtualne realis..., s. 94.

29 Ibidem, s. 88.

30 Ibidem, s. 74, 99-100.
} 
Propozycja Ostrowickiego - oryginalna i pionierska - wywołuje przy tym również pewne wątpliwości, które staram się wskazać w niniejszym tekście. Najbardziej kontrowersyjne jest chyba podstawowe założenie Ostrowickiego dotyczące rozumienia matrycy jako bytu cybernetycznego podlegającego różnorodnym związkom sterowania. „Sterowalność zakłada, że wszystkie zachodzące procesy oraz budowanie związków z otoczeniem dokonuje się na zasadzie zwrotnego oddziaływania struktur matrycy”31. Dodatkowo autor stwierdza: „Matryca może samodzielnie wytwarzać związki i elementy, które nie zostały utworzone przez twórcę matrycy, ale powstały w wyniku jej własnych przekształceń" 32 . Za samodzielny rozwój i przekształcanie matrycy odpowiadają struktury generatywne. Szczególnie rozwinięte struktury generatywne posiadają matryce artystyczne, co przejawia się w bogactwie możliwości interpretacyjnych dzieł sztuki, oraz matryce filozoficzne, co z kolei przejawia się w bogactwie różnorodności opisów rzeczywistości ${ }^{33}$.

31 Ibidem, s. 68-69.

32 Ibidem, s. 70.

33 J. Dębowski wskazuje tu na pewne podobieństwo do koncepcji trzech światów K.R. Poppera. Jak wiadomo, wyróżnił on: 1) W-1 - w skład tego świata wchodzą otaczające nas przedmioty, zarówno te, które postrzegamy, jak i elementy mikroświata, o których mówi fizyka; to przedmioty, stany rzeczy, zdarzenia istniejące w sposób realny; to świat najbardziej rzeczywisty z trzech wyróżnionych; 2) W-2 - świat naszych doznań i przeżyć psychicznych, behawioralnych dyspozycji do działania (zarówno świadomych, jak i podświadomych), czyli świat naszych subiektywnych myśli, wyobrażeń, uczuć, przeżyć, emocji; 3) W-3 - „świat obiektywnych tworów ludzkiego umysłu”; świat obiektywnych treści myśli; świat wiedzy obiektywnej, świat wytworów kultury, do którego należą m.in. twierdzenia, pojęcia i teorie oraz problemy naukowe, treści książek i czasopism, treści dzieł sztuki, mitów, wartości etyki, przedmioty matematyczne, instytucje (język, prawo, religia), a także problemy i sytuacje problemowe, stany dyskusji. Istotną cechą W-3 jest teza o jego zasadniczej autonomii, którą Popper łączy z tym, że W-3 jest wytworem człowieka. Autonomia W-3 polega na tym, że chociaż jest on wytworem ludzi, staje się niezależny od ich woli, kieruje się niezamierzonymi i niezaplanowanymi przez człowieka regułami czy prawami oraz wywiera konkretny wpływa poprzez W-2 (ludzką świadomość) na kształtowanie W-1 (przedmioty fizyczne). Na przykład teorie naukowe są dziełem człowieka, ale zawierają nowe, nieprzewidziane konsekwencje i rodzą autonomiczne problemy. Każdemu ze światów Popper przypisuje odrębny sposób istnienia, ale jednocześnie poszukuje tego, co w nich wspólne. Proponuje, by za istniejące uznać te przedmioty, które mają zdolność oddziaływania na siebie. Czyli dla Poppera być to znaczy mieć zdolność oddziaływania. Można tu mówić o „spirali sprzężeń zwrotnych”, ciągłym wzajemnym oddziaływaniu, wzbogacaniu i umacnianiu tych trzech światów. Szczególną rolę odgrywa W-2, który pośredniczy pomiędzy W-1 a W-3 (pomiędzy tymi światami bezpośredni kontakt jest niemożliwy). Świat W-2 jest tworem świata W-1 i twórcą świata W-3. W wyniku oddziaływania W-3, poprzez W-2, na W-1 powstają nowe przedmioty świata W-1, takie jak książki, obrazy, partytury, których treści stanowią część świata W-3. Popper uznaje te sprzężenia zwrotne między trzema światami za podstawowy element częściowo świadomego kształtowania rzeczywistości. „My, ludzie, wkraczamy świadomie w tę spiralę sprzężeń zwrotnych. My i nasz ludzki umysł, nasze marzenia, stawiane przez nas cele naszego działania. My jesteśmy inicjatorami określonego dzieła, twórcami określonego produktu, 
Otwartość na interpretacje jest cechą właściwą wszelkim tworom świadomości. Według Ingardena jest to jedna z podstawowych różnic pomiędzy przedmiotami realnymi a czysto intencjonalnymi. Przedmioty realne są zupełne w swoim uposażeniu, co oznacza, że dla każdej własności albo ta własność, albo własność dopełniająca jest posiadana przez dany przedmiot. Natomiast wszelkie twory intencjonalne cechują się niezupełnością ontologiczną, czyli ani dana własność, ani jej negacja nie są tym przedmiotom przypisane (np. Sherlock Holmes ani nie jest sierotą, ani nie-sierotą). Jest to wynikiem skończoności naszej świadomości - dowolnemu przedmiotowi intencjonalnemu można przypisać jedynie skończoną liczbę własności. W ten sposób powstają miejsca niedookreślenia/luki, które podmiot może zapełniać swoimi interpretacjami. Trudno jednak mówić tutaj o samodzielnym wytwarzaniu związków czy elementów przez matrycę, którą może być np. powieść lub pewien system filozoficzny. Powieść nie generuje swoich interpretacji samodzielnie, lecz są one tworzone przez podmiot podczas czytania. Wytwarzanie jest zawsze związane z jakimś rodzajem aktywności - powieść nie generuje sama z siebie różnorodnych interpretacji, tylko stwarza jedynie taką możliwość podmiotowi. Dla dokonania interpretacji niezbędny jest czynny udział podmiotu. Powieści nie tyle generują/wytwarzają, co implikują, umożliwiają wyprowadzanie wniosków lub dokonywanie interpretacji przez podmiot. Trudno też powiedzieć, na czym miałoby polegać wzajemne oddziaływanie na siebie dwóch różnych matryc-powieści - bez udziału podmiotu relacją zachodzącą pomiędzy nimi będzie wzajemna bierność. Aktywność/działanie zdaje się być ulokowane zawsze po stronie podmiotu, a nie jego (czysto) intencjonalnego wytworu. Być może problem ten dałoby się jakoś rozwiązać, doprecyzowując pojęcie sterowania, lecz niestety Ostrowicki pozostawia tę kwestię otwartą i odwołuje się do tajemnicy czarnej skrzynki. Innym sposobem rozwiązania tego problemu jest ograniczenie zakresu pojęcia „wirtualności”. Wówczas możliwe byłoby mówienie o interaktywności bytów genetycznie zakorzenionych w świadomości podmiotu. Jednak konsekwencją takiego ujęcia by-

lecz jednocześnie jesteśmy przez nasze wytwory kształtowani. Właściwie to jest twórcze w człowieku: że my, tworząc, równocześnie przekształcamy samych siebie. Kształtowanie rzeczywistości jest więc naszym dziełem; jest procesem, który nie może być właściwie zrozumiany, o ile nie spróbujemy zrozumieć wszystkich jego trzech stron, tzn. opisanych trzech światów, i o ile nie spróbujemy zrozumieć różnych rodzajów i sposobów wzajemnego oddziaływania na siebie tych trzech światów" - K.R. Popper, Auf der suche nach einer besseren Welt, München 1961, cyt. za: L. Węsierska, Przedmioty czysto intencjonalne a obiekty trzeciego świata, [w:] R. Poczobut, L. Węsierska, Z badań nad sprzecznościa, przedmiotami czysto intencjonalnymi oraz Popperowskim trzecim światem, Lublin 1996, s. 142. Popper o swojej koncepcji trzech światów pisał m.in. w: K.R. Popper, J.C. Eccles, The Self and Its Brain. An Argument for Interactionism, Berlin-Heildelberg 1986 (zwłaszcza rozdział 2: P2 The World 1, 2 and 3, s. 36-50); K.R. Popper, Epistemologia bez podmiotu poznajacego, [w:] Wiedza obiektywna, Warszawa 1992, s. 148-206. 
Pobrane z czasopisma Annales I - Philosophy and Sociology http://philosophia.annales.umcs.pl Data: 26/04/2023 11:31:22

Pojęcie matryc M. Ostrowickiego - analiza i krytyka

łoby zawężenie obowiązywalności opisu jedynie do wąsko pojmowanej wirtualności, co jest niezgodne z celem wyznaczonym przez Ostrowickiego - systemowego i jednorodnie systematycznego opisu całości podmiotowej rzeczywistości. Przywołując Ingardena, można powiedzieć, że zgodnie z koncepcją Ostrowickiego sfera wirtualności - postrzegana jako twór świadomości - byłaby zakresowo równoważna sferze przedmiotów czysto intencjonalnych, czyli wszelkich tych przedmiotów, które są projektowane świadomościowo. Teoria Ostrowickiego proponuje zatem bardzo szerokie rozumienie pojęcia wirtualności - wirtualny to tyle, co wytworzony świadomościowo. Tak szeroki sposób pojmowania wirtualności może prowadzić do zatarcia specyfiki tej sfery - mianowicie do tego, że jest to generowane komputerowo środowisko cyfrowe (z elementami którego możemy wchodzić w ucieleśnione interakcje), a z taką konotacją właśnie najczęściej używa się obecnie pojęcia wirtualności. Z punktu widzenia teorii matryc bytem wirtualnym jest zarówno Lara Croft - postać literacka, jak i Lara Croft - postać z gry komputerowej. Tymczasem zdaje się, że pomiędzy tymi bytami występuje zasadnicza różnica - w ucieleśnione interakcje możemy wchodzić z elementami środowiska cyfrowego (w szczególności z elementami gry komputerowej), co jednak jest niemożliwe w przypadku postaci literackich. Intuicyjnie więc wydaje się nam, że należałoby odróżniać obiekty wirtualne od fikcyjnych.

Można też zastanawiać się, czy faktycznie podmiot w każdej sytuacji może kształtować sferę wirtualną zgodnie ze swoimi potrzebami i dążeniami - „w wirtualności człowiek może podążać w prawie nieograniczonym kierunku"34. Trzeba pamiętać o tym, że w obrębie zrealizowanej już sfery wirtualnej (w obrębie symulacji komputerowej) trzeba stosować się do reguł/prawidłowości ustalonych przez twórców danej symulacji. Zatem twierdzenie o dowolnym kształtowaniu sfery wirtualnej dotyczy tylko twórcy danej symulacji, ale już nie jej uczestników. Jeżeli uznamy zaproponowany przez Ostrowickiego opis rzeczywistości za adekwatny - to znaczy, że światem podmiotu jest wirtualne realis - to musimy również pogodzić się z konsekwencją, że podmiot nie wkracza do dziewiczej krainy, w której wszelkie możliwości są mu dostępne. Przeciwnie - rozwijane od tysięcy lat wirtualne realis podmiotu jest wypełnione ogromną liczbą już zrealizowanych matryc. Wszystkie te matryce ewoluują, wchodzą we wzajemne interakcje zarówno między sobą, jak i z niezliczonymi podmiotami, a wszystko to realizuje nie tylko nowe możliwości, ale też tworzy różnorakie ograniczenia, które z kolei mogą równie skutecznie uniemożliwiać realizowanie potrzeb podmiotu, jak ograniczenia występujące w świecie realnym.

Ponadto dyskusyjne pozostaje twierdzenie Ostrowickiego, że człowiek „po-

${ }^{34}$ M. Ostrowicki, Wirtualne realis..., s. 89-90. 
szukując bezpiecznego, znanego środowiska, tworzy alternatywną w stosunku do realności, własną sferę istnienia w postaci matryc" ${ }^{35}$. Niewątpliwie prawdą jest, że sfera wirtualna zabezpiecza ludzką egzystencję w sposób (przynajmniej na razie) nieosiągalny w świecie realnym - niezwykle pociągające $w$ wirtualności jest to, że zdaje się praktycznie likwidować letalność. Jednak poza bezpieczeństwem egzystencjalnym wirtualność oferuje też dużą dozę opresyjności. Religie nakładające na wiernych szereg ograniczeń i straszące wiecznym potępieniem w przypadku łamania ustalonych zasad; niezwykle rozbudowane i zagmatwane systemy prawne, które często - wbrew deklarowanej zasadzie równości - są łagodne dla nielicznych, a opresyjne dla większości; cała sfera konwencjonalnych i rytualnych zachowań, często dusząca oryginalność i spontaniczność; niewydolne systemy ekonomiczne, utwierdzające nas w przekonaniu o realnej wartości pieniądza; wszechobecna reklama, nieustannie wzmacniająca potrzebę konsumpcji; schematy reakcji emocjonalnych wywołujące frustracje i depresje; systemy wzmacniające przekonanie, że zysk, kariera i sukces są gwarancją dobrego życia - to jedynie nieliczne przykłady spośród miriad otaczających nas opresyjnych i represyjnych matryc składających się na sferę wirtualną (w rozumieniu Ostrowickiego), w obrębie której przychodzi nam wieść nasze życie.

Ostrowicki twierdzi również, iż sfera wirtualna zawiera takie bogactwo treści świadomości, iż „można zasugerować, że matryce są swoiście bogatsze od realności - tak jakby matryce posiadały nadmiarowość treści w stosunku do zakładanej realności" ${ }^{36}$. Przede wszystkim - jeżeli jest tak, jak twierdzi Ostrowicki, że nasz dostęp do sfery realności jest mocno ograniczony albo nawet niemożliwy - należy określić, na jakiej podstawie można sformułować twierdzenie o większym bogactwie wirtualności. Odwołując się do Ingardena, według którego przedmioty realne są zupełne ontologicznie, natomiast przedmioty (czysto) intencjonalne są niezupełne ontologicznie, można sformułować tezę odwrotną, mianowicie że to sfera realna przewyższa swoim bogactwem sferę wirtualną. Jeżeli świadomość wirtualizuje treści ze świata realnego, to - jak na to wskazuje dotychczasowe doświadczenie - owa wirtualizacja często polega na selekcji i uproszczeniu. Dobrym przykładem jest tu HUD (Head-Up Display) - wyświetlacz używany w lotnictwie, składający się z przezroczystej osłony na oczy, na której to osłonie wyświetlane są dane dla pilota sterującego samolotem. Komputer selekcjonuje i filtruje dane $\mathrm{z}$ realnego świata tak, aby były wyświetlane wyłącznie te, które są istotne dla pilotowania samolotu ${ }^{37}$. Pomimo swojej (pozornej) oczywistości twierdzenie o większym bogactwie tre-

\footnotetext{
35 Ibidem, s. 86.

36 Ibidem, s. 111.

37 Zob. także: ibidem, s. 89.
} 
Pobrane z czasopisma Annales I - Philosophy and Sociology http://philosophia.annales.umcs.pl Data: 26/04/2023 11:31:22

Pojęcie matryc M. Ostrowickiego - analiza i krytyka

ściowym sfery wirtualnej w stosunku do świata realnego może okazać się fałszywe, a nawet jeśli tak nie jest, to potrzebuje ono lepszego uzasadnienia ${ }^{38}$.

W rozważaniach nad wirtualnością Ostrowicki przyjmuje podobieństwo pomiędzy źródłem (świadomością) a wytworem (sferą wirtualną). „Świadomość jak i sfera wirtualna są odległe od takich pojęć, jak np. fizyczność czy realność, raczej zbliżają się do takich pojęć, jak immateria lub intencjonalność"39. Dlatego właśnie sfera wirtualna jest bliższa i łatwiej dostępna człowiekowi niż świat realny. „Świadomość wytwarza matryce, które stają się rzeczywistością obiektywną w postaci sfery wirtualnej. [...] świat realny nie jest jej [świadomości] wytworem ani nie jest przekonujący jako istniejąca rzeczywistość" ${ }^{40}$. Podmiot zyskuje nieograniczony i bezpośredni dostęp do sfery wirtualnej oraz zdolność bezwarunkowego funkcjonowania w obrębie tej sfery, gdyż sfera ta jest tworem podmiotu ${ }^{41}$. Kluczowe znaczenie ma tutaj sposób rozumienia świa-

38 H. Dreyfus i S. Dreyfus - odwołując się do Heideggerowskiego pojęcia otwierania nowych światów (open up new worlds) - przedstawiają argumenty na rzecz tezy, iż Matrix (a w konsekwencji każda symulacja komputerowa) jest istotnie uboższy od świata realnego. Cała nasza historia - jak twierdzą - pokazuje, że w naturze człowieka leży zdolność otwierania nowych światów. Na przykład: Jezus otworzył dla ludzi nowy świat wartości; Kartezjusz odkrył Ja, dzięki czemu pomógł otworzyć świat modernistyczny; M.L. King otworzył nowy świat dla afroamerykanów; A. Einstein otworzył świat fizyki relatywistycznej itd. W symulacjach komputerowych nie ma możliwości wyjścia poza zaprogramowaną rzeczywistość oraz odsłaniania nowych światów - nie chodzi o to, by złamać reguły gry (co próbuje zrobić Neo w Matrixie), lecz o to, by stworzyć nową grę. M. Heidegger uważał, iż wolność/zdolność otwierania nowych światów jest specyficznie ludzka, co implikuje, że nie ma żadnego ustalonego zbioru preistniejących światów możliwych. Dany świat istnieje tylko wówczas, gdy zostanie odsłonięty. Nie da się zatem zaprogramować komputera tak, by dana symulacja komputerowa obejmowała wszystkie światy możliwe, które kiedyś mogą zostać otworzone przez człowieka. Sztuczna inteligencja nie jest w stanie zaprogramować takiej możliwości otwierania radykalnie nowych światów. Zaprogramowana kreatywność to oksymoron. Jeśli otwieranie nowych światów leży w naturze człowieka, to wyjaśnia to, dlaczego człowiek odczuwa tak dużą radość, wkraczając do nowego świata. Jeśli kiedyś przeżyliśmy coś takiego, rozumiemy, dlaczego lepiej przebywać w realnym świecie, a nie w jego symulacji. Nie jest zatem istotne, czy nasze przekonania są prawdziwe albo czy jesteśmy wystarczająco dzielni, by stawić czoła otaczającej nas rzeczywistości (która może być symulowana) - ważne jest to, czy jesteśmy zamknięci w świecie rutyny i banału naszych codziennych zachowań i przyzwyczajeń czy też jesteśmy wolni tak, że możemy przekształcać świat i siebie. Zob. H. Dreyfus, S. Dreyfus, The Brave New World of The Matrix, 2002, http://whatisthematrix.warnerbros.com/rl_cmp/phi.html [dostęp: 27.04.2008]. Należy pamiętać, że Ostrowicki przyjmuje bardzo szerokie znaczenie pojęcia wirtualności, przy którym pojęcie to jest zakresowo równoważne pojęciu wytworzony świadomościowo/będący wytworem podmiotu. Przy takim ujęciu sugerowane ograniczenia środowisk symulowanych komputerowo wskazane przez Dreyfusa i Dreyfusa nie dotyczą tak rozumianej sfery wirtualnej. Przeciwnie, wzmacniają one argumentację Ostrowickiego za tym, że sfera wirtualna (będąca tworem podmiotu) jest istotnie bogatsza od zakładanego/domniemanego świata realnego.

39 M. Ostrowicki, Wirtualne realis..., s. 114.

40 Ibidem, s. 110.

${ }^{41}$ Ibidem, s. 71, 90 . 
domości, jej statusu i genezy. Ostrowicki de facto przyjmuje Kartezjański pogląd na świat, mocno podkreślając odrębność (domniemanego) świata realnego i świadomości/podmiotu.

Sfera wirtualna posiada silniejszy status ontologiczny w stosunku do świata realnego - podobnie jak postrzegany przez nas świat jest jedynie cieniem Platońskich idei ${ }^{42}$. Sfera wirtualna jest wytworem świadomości, a zatem jest ontologicznie względem świadomości pochodna. Świadomość ma więc silniejszy status ontologiczny w stosunku do wirtualności. A ponieważ status ontologiczny wirtualności jest silniejszy w stosunku do realności, to bezpośrednią konsekwencją tych założeń jest to, że świadomość nie jest elementem świata realnego oraz posiada silniejszy status ontologiczny w stosunku do realności. „Przyjmujemy, że podmiot do realności dotrzeć (w ogóle lub w pełni) nie jest zdolny, zatem świadomość wytwarza matryce jako własną domenę dla działania lub istnienia podmiotu"43. Możliwe więc, że sfera wirtualna - tak szeroko rozumiana - jest jedyną sferą istnienia i działania podmiotu ${ }^{44}$.

\section{BIBLIOGRAFIA}

Dennett D., Intentional Stance, Cambridge-London 1987.

Dębowski J., Świadomość, poznanie, naoczność poznania, Lublin 2001.

Dreyfus H., Dreyfus S., The Brave New World of The Matrix, 2002, http://whatisthematrix.warnerbros.com/rl_cmp/phi.html [dostęp: 27.04.2008].

Gurczyński J., Czym jest wirtualność. Matrix jako model rzeczywistości wirtualnej, Lublin 2013.

Ingarden R., Spór o istnienie świata, t. 2, Warszawa 1961.

Ostrowicki M., Tożsamość człowieka w środowisku elektronicznym, „Kwartalnik Filmowy” 2008, nr 62-63.

Ostrowicki M., Wirtualne realis. Estetyka w epoce elektroniki, Kraków 2006.

Popper K.R., Auf der suche nach einer besseren Welt, München 1961.

Popper K.R., Epistemologia bez podmiotu poznajacego, [w:] Wiedza obiektywna, Warszawa 1992.

Popper K.R., Eccles J.C., The Self and Its Brain. An Argument for Interactionism, Berlin-Heildelberg 1986.

${ }^{42}$ Ibidem, s. 92.

43 Ibidem, s. 74.

44 J. Dębowski zauważa, iż z punktu widzenia teorii Ingardena świadomość ma formę procesu, a więc jest przedmiotem czasowo określonym i - wskutek tego - realnym. Nie jest też tak, że świadomość dla swego zaistnienia (jako proces) nie wymaga żadnego substratu. Właśnie z powodu swej formy wymaga podłoża, na którym jako proces (strumień przeżyć) może się pojawić. Potwierdza to dokonane już spostrzeżenia, iż teoria matryc Ostrowickiego pozostaje niezgodna z podstawowymi ustaleniami teorii świadomości i intencjonalności Ingardena, natomiast wyraźnie widoczne są jej Kartezjańskie inspiracje oraz proponowane rozwiązania. 
Weberman D., The Matrix Simulation and the Postmodern Age, [w:] W. Irwin (ed.), The Matrix and Philosophy. Welcome to the Desert of the Real, Chicago 2002.

Węsierska L., Przedmioty czysto intencjonalne a obiekty trzeciego świata, [w:] R. Poczobut, L. Węsierska, Z badań nad sprzecznościa, przedmiotami czysto intencjonalnymi oraz Popperowskim trzecim światem, Lublin 1996.

\section{SUMMARY}

The article discusses the concept of the matrix presented by M. Ostrowicki. The concept is Ostrowicki's original thought and relates to the way that virtual reality exists and is understood. The basic term is a matrix understood in a peculiar way represented in the cybernetic approach which is fully compatible with the digitality of virtual reality. In the article, the author presented the critical analysis of the concept stressing its limitations based on the very concept of the matrix. It is important, however, to highlight the fact that it was the first fully author's attempt to look at the problem of virtual reality's ontology in general instead of local way.

Keywords: virtual reality; ontology; M. Heim; M. Ostrowicki; matrix

\section{STRESZCZENIE}

W artykule omówiono koncepcję matryc przedstawioną przez M. Ostrowickiego. Jest to jego oryginalna koncepcja, dotycząca sposobu rozumienia oraz istnienia rzeczywistości wirtualnej. Podstawowym pojęciem jest swoiście rozumiana matryca (matrix), w dużym stopniu ujęta na sposób cybernetyczny, co doskonale współgra z cyfrowością rzeczywistości wirtualnej. Przedstawiono krytyczną analizę dotyczącą tej koncepcji, wskazując na pewne jej niedoskonałości, leżące niestety u podstawy samego pojęcia matrycy. Należy jednak zauważyć, że była to pierwsza w pełni autorska próba całościowego, a nie tylko lokalnego, ujęcia problemu ontologii rzeczywistości wirtualnej.

Słowa kluczowe: rzeczywistość wirtualna; ontologia; M. Heim; M. Ostrowicki; matryca 